\title{
PROBLEMATIKA PENDIDIKAN ISLAM; ANTARA DETERMINISME HISTORIS DAN REALISME PRAKTIS
}

\author{
Masykurotus Syarifah \\ STAI Nazhatut Thullab Sampang \\ Email: masykurohs@gmail.com
}

\begin{abstract}
Abstrak:
Pendidikan Islam sampai sekarang dapat dikatakan masih berada dalam posisi problematik antara 'determinisme historis' dan 'realisme praktis'. Di satu sisi, pendidikan Islam belum sepenuhnya keluar dari cita-cita kemuliaan masa lalu hegemoni tentang pemikiran dan peradaban Islam; Sementara di sisi lain, juga 'dipaksa' menerima tuntutan masa kini, terutama yang datang dari Barat, dengan orientasi yang sangat praktis. Perkembangan pendidikan Islam di Indonesia, dapat disimpulkan bahwa basis yang digunakan adalah peradaban pembebasan pemberdayaan. Dasar dari reformasi ini adalah pendidikan dengan konsep keagamaan, demokrasi, toleransi, berbasis hukum, egaliter, menjunjung tinggi martabat manusia, berbasis budaya, berbasis global, anti kekerasan, dan berbasis antikorupsi. Sistem pendidikan Islam di masa kini dan masa yang akan datang perlu dipikirkan dan dibicarakan sebab-sebab permasalahannya, antara lain: Pertama, bahwa penyelenggaraan pendidikan Islam secara formal/ informal belum sesuai dengan pengertian pendidikan Islam itu sendiri; Kedua, bahwa sistem dan metode itu masih dalam lingkaran pendakalan (proses de islamisasi).
\end{abstract}

Kata kunci: Pendidikan, Islam, historis, Realisme Praktis

\section{Abstract:}

Islamic education until now may be said to still be in a problematic position between 'historical determinism' and 'practical realism'. On the one hand Islamic education has not been entirely out of the ideals of the hegomonic past glories of Islamic thought and civilization; while on the other hand, it is also 'forced' to accept the demands of the present, especially those coming from the West, with a very practical orientation. 2) The renewal of Islamic education in Indonesia, it can be concluded that the basis used is empowerment-liberating civilization. The basis of this reform is education with religious foundations, democracy, tolerance building, law-based, egalitarian stance, uphold human dignity, 
cultural-based diversity, global-based, anti-violence, and anticorruption-based. 3) Islamic education system in the present and the future should be considered and discussed the causes of the problem, among others: First, that the implementation of Islamic education in a formal / informal not in accordance with the understanding of Islamic education itself; Second, that the systems and methods are still in the circle of delinquency (de Islamization process).

Keywords: Education, Islam, historical, realism Practical

\section{Pendahuluan}

Islam sebagai sebuah agama tidak saja memiliki pendekatan teologis sebagaimana kisah-kisah nabi yang diceritakan dengan penggambaran yang jelas dalam al-Qur'an, tetapi lebih dari itu Islam juga tidak mengabaikan kausalitas sosial, dengan demikian harus ada titik iquilibrium antara pendekatan teologis dan pendekatan sosiologis.

Pemikiran pembaruan pendidikan Islam berada pada dua titik antara determinisme historis disatu sisi dan realisme praktis disisi lain. Posisi problematik determinisme historis dapat dilihat dari masih kuatnya nuansa nostalgia pada kejayaan Islam di masa lalu dalam beragam aspek pendidikan Islam di Indonesia. Sedangkan problematika realisme praktis antara lain tergambar dari masih belum maksimalnya pendidikan Islam dalam menghadapi dan menjawab perkembangan kekinian sebagai tantangan yang ada di depannya.

Pendidikan Islam dikaitkan dengan konsepsi kejadian manusia yang dari sejak awal kejadiannya sebagai makhluk Tuhan yang paling sempurna yang dibekali potensi akal dan ilmu, maka itu merupakan proses panjang yang tidak berkesudahan sehingga siap untuk memikul amanat Tuhan dan tanggung jawab, sepanjang dunia masih ada. Oleh sebab itu problematika pendidikan Islam yang muncul selalu complicate serumit persoalan manusia itu sendiri.

Pendidikan merupakan bagian terpenting dari kehidupan manusia. Belajar berarti rangkaian kegiatan menuju "pendewasaan" guna menuju kehidupan yang lebih berarti. Oleh karena itu berbagai pandangan yang menyatakan bahwa pendidikan itu merupakan proses budaya untuk mengangkat "harkat dan martabat" manusia dan berlangsung sepanjang hayat. Apabila demikian, maka pendidikan memegang peranan yang menentukan eksistensi dan perkembangan manusia, "karena 
pendidikan merupakan usaha melestarikan, dan mengalihkan serta mentransformasikan nilai-nilai kebudayaan dalam segala aspeknya kepada generasi penerus" untuk mengangkat harkat dan martabat manusia.

Berbicara tentang problematika pendidikan Islam sebelumnya kita harus tahu tentang Islam itu sendiri. Penulis mengajak tidak hanya potongan-potongan ayat yang diambil untuk kepentingan egoisme dan nafsu kesombongan. Banyak realitas yang ada dalam perkembangan Islam sehingga muncul sejarah yang tidak sekedar cerita atau rekayasa. Sejarah bukanlah mitos, bukan pula suatu proyek arbitrer yang sama sekali tidak mempunyai kausalitas sosial. Pemahaman yang utuh terhadap Islam tentulah harus menyertakan pula dimensi sejarah (historis) yang merupakan bangunan dasar atas situasi masa kini. Kita tahu yang banyak terjadi "banyak orang yang belajar sejarah, tetapi tidak belajar dari sejarah".

Sementara dalam konteks keindonesiaan, sejatinya pendidikan Islam juga mampu merespon dinamika kehidupan yang terjadi dinegara kita yang meliputi gerakan separatis, munculnya aksi terorisme dan yang lainnya. Maka kemudian, sebagai bentuk ikhtiar itu, para pelaku pendidikan harus senantiasa melakukan pembenahan, koreksi dan evaluasi serta berfikir dinamis dan produktif. Upaya ini misalnya telah dilakukan oleh Mukti Ali dalam usahanya memformulasikan lembaga madrasah dan pesantren dengan cara memasukkan materi pelajaran umum ke dalam lembaga-lembaga yang pendiriannya diorientasikan untuk tafaqquh fí al-dîn. Demikian pula yang dilakukan oleh Harun Nasution dalam upayanya menghilangkan dikotomi ilmu agama dan ilmu umum di lembaga pendidikan tinggi Islam, khususnya IAIN Jakarta, dengan cara pendekatan kelembagaan dan kurikulum. Pendekatan kelembagaan telah merubah status IAIN Jakarta menjadi Universitas Islam Negeri (UIN) yang berimplikasi pada pengembangan kurikulum terintegrasi antara ilmu-ilmu agama dan ilmu-ilmu umum. ${ }^{1}$

Islam sebagai sebuah agama tidak saja memiliki pendekatan teologis sebagaimana kisah-kisah nabi yang diceritakan dengan penggambaran yang jelas dalam al-Qur'an, tetapi lebih dari itu Islam juga tidak mengabaikan kausalitas social. Untuk mengingat pendidikan merupakan kebutuhan penting bagi setiap manusia,

1 Moh. Wardi, "Problematika Pendidikan Islam Dan Solusi Alternatifnya (Perspektif Ontologis, Epistemologis dan Aksiologis)" Tadris Jurnal Pendidikan Islam STAIN Pamekasan, Volume 8 Nomor 1 Juni 2013, 55. 
negara, dan pemerintah, maka "pendidikan harus selalu ditumbuhkembangkan secara sistematis oleh para pengambil kebijakan yang berwenang di Negara ini". Berangkat dari kerangka ini, maka upaya pendidikan yang dilakukan suatu bangsa selalu memiliki hubungan yang sangat signifikan dengan rekayasa bangsa tersebut dimasa mendatang, sebab pendidikan selalu dihadapkan pada perubahan, baik perubahan zaman maupun perubahan masyarakat. Oleh karena itu, mau tidak mau pendidikan Agama Islam harus didesain mengikuti irama perubahan tersebut, kalau tidak pendidikan akan ketinggalan. Tuntutan pembaharuan pendidikan menjadi suatu kaharusan dan "pembaruan" pendidikan selalu mengikuti dan relevan dengan kebutuhan masyarakat baik pada konsep, kurikulum, proses, fungsi, tujuan, manajemen lembaga-lembaga pendidikan, dan sumber daya pengelola pendidikan. Tentunya disini dibutuhkan kejelian dalam berfikir dan menganalisis.

\section{Pembahasan}

Sebelum penulis membahas tentang determinisme historis' dan 'realisme praktis pendidikan Islam, akan sedikit menyinggung tentang sejarah Islam. Sejarah dalam pandangan Ibn Khaldun ${ }^{2}$

\footnotetext{
${ }^{2}$ Ibn Khaldun telah mendapat perhatian khusus daripada bidang-bidang lainnya. Hal ini terbukti dari banyaknya penghargaan yang diberikan kepadanya. Toynbee misalnya menyatakan bahwa Ibn khaldun dengan kitab alMuqadimah bagian Kitab al-Ibar-nya, ia telah menciptakan dan menyusun filsafat sejarah yang tidak diragukan lagi merupakan karya terbesar dalam bidang itu yang pernah diciptakan manusia dalam waktu dan tempat manapun. Robert Flint, seorang pakar sejarah filsafat berkebangsaan Inggris yang pendapatnya dikutip oleh Issawi, menyatakan bahwa dalam bidang filsafat sejarah, literatur Arab dihiasi oleh satu nama yang sangat cemerlang, yaitu Ibn Khaldun. Baik dunia Kristen klasik maupun Pertengahan, tidak sanggup menunjukkan seorang pun yang dapat mendekati kecemerlangannya. Plato, Aristoteles, dan Agustine bukanlah tandingannya (Demikian pula George Sarton, seorang ahli sejarah ilmu pengetahuan dari Amerika telah memandang Ibn Khaldun sebagai ahli sejarah, politik, sosiologi, dan ahli ekonomi, seorang yang telah mendalami persoalan-persoalan manusia, meneliti kehidupan manusia sekarang dan masa mendatang. Ia adalah seorang ahli filsafat sejarah pertama yang menjadi pembuka jalan bagi Machiavelli, Bodin, Comte, dan Cournot, Ketenaran dan kemegahan Ibn Khaldun disebabkan karya monumentalnya, al-Muqaddimah. Di dalam al-Muqaddimah, Ibn Khaldun telah membangun teori-teorinya tentang sejarah, ilmu sosial, dan kebudayaan. Gaston Bouthoul secara anatomis telah mengkaji kandungan al-Muqaddimah. Menurutnya, ada tiga kajian besar yang terdapat dalam kitab al-Muqaddimah, yaitu ilmu sejrah, sosiologi, dan ilmu politik. Philips K. Hitti, History Of The
} 
bukan sekedar ceritera kronik tentang berbagai peristiwa masa lalu, tetapi sejarah juga berarti menyajikan kritik terhadap data dan berita yang ada, di samping analisis terhadap berbagai faktor yang menyebabkan terjadinya suatu peristiwa. Ibn Khaldun, ia terkenal di Barat dengan metode sejarahnya. Diakui oleh Philip K. Hitti bahwa 'tidak ada penulis Arab dan Eropa yang mempunyai pemikiran sejarah yang jelas seperti Ibn Khaldun yang telah mengulasnya secara filosofis. Semua orang sepakat bahwa Ibn Khaldun adalah ahli filsafat sejarah terbesar selama negara Islam terbentang dan salah seorang ahli filsafat sejarah terbesar selama dunia berkembang'. Reputasi Ibn Khaldun secara realitas memang diakui dan dikagumi oleh kaum intelektual, baik di kalangan Barat maupun Timur. Sungguh banyak predikat yang disandangkan kepadanya. Ibn Khaldun terkadang disebut sebagai sejarawan, ahli filsafat sejarah, sosiolog, ekonom, ahli geografi, ilmuwan politik, dan lain-lain. Banyaknya predikat yang disandangnya ini membuktikan bahwa Ibn Khaldun adalah seorang cendekiawan Muslim yang keilmuannya hampir menyentuh seluruh sendi-sendi kehidupan manusia. Akan tetapi, dalam bidang sejarah dan filsafat sejarah, Pandangan inilah yang menyebabkan Ibn Khaldun dianggap sebagai puncak sejarawan naratif interpretative di kalangan cendekiawan Arab. Oleh karena sejarah mengandung suatu penyelidikan kritis dan mencari kebenaran; suatu pengetahuan mendalam tentang 'bagaimana'dan 'mengapa' suatu peristiwa terjadi, maka sejarah menurut Ibn Khaldun dipandang sebagai bagian dari hikmah atau filsafat. Metode sejarah yang dikemukakan oleh Ibn Khaldun meliputi empat tahap. Menurutnya dalam penelitian sejarah membutuhkan: (1) Sumber yang beragam, (2) Pengetahuan yang bermacam-macam, (3) Perhitungan yang tepat dan ketekunan, dan (4) Memeriksa sumber-sumber yang dipakai secara teliti. ${ }^{3}$ Keempat persyaratan yang dikemukakan oleh Ibnu Khaldun tersebut sepadan dengan tahap-tahap penelitian yang dikemukakan oleh para ahli sejarah yang datang kemudian, yang disebut metode sejarah kritis, yang meliputi empat tahap, yaitu: heuristik, kritik sumber, interpretasi, dan penulisan.

Arabs, first edition, and six edition, (USA: tt, 1968), 568. Lihat Juga: Toto Suharto, Pendidikan Berbasis Masyarakat Organik, (2003), 16.

${ }^{3}$ Ibn Khaldun, al-Muqaddimah, Terjm. Ahmadie Thoha, Cet. 1 (Jakarta: Pustaka Firdaus, 1986), 12-13. 
Bagaimanapun juga asal usul Islam tidak bisa dilepaskan dari konteks sosial, dengan Makkah ${ }^{4}$ sebagai settingnya, sebagaimana asbab al-nuzul ayat-ayat al-Qur'an. Kesadaran yang tepat diperlukan untuk memahami sesuatu dan mengambil hikmah dari peristiwa-peristiwa sejarah, dan bukan semata-mata persepsi inderawi yang dimiliki setiap orang.

Dari latar historis, jelaslah bahwa Islam sebagai agama memiliki potensi pembebasan atau yang biasa disebut sebagai agama pembebasan. Islam pada kenyataannya tidak hanya gerakan keagamaan semata, namun lebih dari itu merupakan gerakan transformasi yang tentu saja mengembangkan paradigma transformasi. Nabi Muhammad saw. Telah diutus untuk membimbing dan membebaskan rakyat Arabia dari krisis moral dan sosial yang lahir dari penumpukan kekayaan yang berlebihan, sehingga menyebabkan kebangkrutan dan kesemrawutan sosial. Masa itu Islam merupakan tantangan serius bagi kaum monopolis Makkah. ${ }^{5}$

\section{Problematika Reformasi Pendidikan Islam}

Urgensi pendidikan bagi kehidupan manusia, mempunyai peranan sentral dalam mendorong individu dan masyarakat untuk meningkatkan kualitasnya dalam segala aspek kehidupan demi mencapai kemajuan, dan untuk menunjang perannya di masa mendatang. Hal ini terbukti dalam kehidupan sekarang, pendidikan tampil dengan daya pengaruh yang sangat besar dan menjadi

4 Makkah adalah tempat kelahiran Islam, yang dikenal sebagai pusat perdagangan internasional. Banyak pedagang elit di sana, para konglomerat memonopoli perdagangan di kawasan kerajaan Byzantium. Hal ini mereka lakukan demi mengeruk keuntungan tanpa mendistribusikannya kepada suku yang miskin dan membutuhkan. Tentu saja kelompok pedagang ini berbeda dengan suku asli Islam Makkah seperti Badui misalnya yang memiliki cara pandang dan etika kesukuan tertentu, misalnya watak egalitarian (kebersamaan). Disinilah benturan terjadi antara kaum pedagang yang senantiasa mengembangkan kepemilikan pribadi, memperbanyak keuntungan, menumbuhkan disparitas ekonomi dan pemusatan kekayaan. Ini yang membuat berbeda dengan suku asli Makkah. Maka Allah SWT. Mengutus Nabi Muhammad untuk menyelamatkan Makkah. Dan dengan tegas Nabi Muhammad menentang praktik akumulasi harta kekayaan dan mengingatkan bahaya dan konsekuensi dari tidak membelanjakan harta di jalan Allah, kemudian bersama orang-orang lemah yang termarjinalkan dari persaingan bebas di Makkah, Nabi Muhammad bergabung dalam asosiasi yang dikenal atas dasar sebutan mereka terhadap persekutuan ini dengan nama hilf al-fudul (tiga orang tulus).

5 Muh. Hanif Dhakiri, Paulo Freire Islam Pembebasan, (Jakarta: Penerbit Pena, 2000), 81-85. 
variabel pokok masa depan manusia baik pada konsep, kurikulum, proses, fungsi, tujuan, manajemen lembaga-lembaga pendidikan, dan sumber daya pengelola pendidikan.

Pendidikan Islam hingga kini boleh dikatakan masih saja berada dalam posisi problematik antara 'determinisme historis' dan 'realisme praktis'. Di satu sisi pendidikan Islam belum sepenuhnya bisa keluar dari idealisme kejayaan pemikiran dan peradaban Islam masa lampau yang hegomonik; sementara di sisi lain, ia juga 'dipaksa' untuk mau menerima tuntutan-tuntutan masa kini, khususnya yang datang dari Barat, dengan orientasi yang sangat praktis. Dalam dataran historis empiris, kenyataan tersebut acap kali menimbulkan dualisme dan polarisasi sistem pendidikan di tengah-tengah masyarakat muslim sehingga agenda transfomasi sosial yang digulirkan seakan berfungsi hanya sekedar 'tambal sulam' saja. Oleh karena itu, tidak mengherankan apabila di satu sisi kita masih saja mendapatkan tampilan 'sistem pendidikan Islam' yang sangat tradisional karena tetap memakai 'baju lama'.6

Ada beberapa point tentang keadaan pendidikan Islam pada masa kini.

1. Sistem pendidikan sekuler mendapat dana besar dari pemerintah sedangkan pendidikan Islam, kebanyakan usaha swasta/swadaya masyarakat.

2. Hasil dari pendidikan sekuler adalah manusia yang tidak memiliki ketajaman wawasan tentang Islam dan cita-cita Islam.

Maka tugas terberat yang dihadapai Umat Islam sekarang ini adalah memecahkan masalah pendidikan. Tidak ada harapan akan kebangkitan Umat Islam kecuali dengan merubah system pendidikan dan memperbaiki kesalahan-kesalahannya. Dalam hal Reformasi Pendidikan, maka Rasulullah saw. Adalah prototype yang terbaik, bagaimana orang yang ummi (buta huruf), hanya dalam jangka waktu 23 tahun telah melahirkan satu "Generasi yang Unik" (Jiil al-Fariid) dan tidak akan ada lagi satu peradaban yang bisa melahirkan manusia-manusia jenius seperti para sahabat Nabi Muhammad saw. Oleh karenanya, dunia Islam mesti bangkit dari keterpurukannya, berupaya kembali meneruskan penemuan

\footnotetext{
${ }^{6}$ Untuk menelusuri bagaimana penyebaran Ilmu dalam Islam di masa klasik, mengutip pendapat Armani Arief mengatakan bahwa penting melihat keberadaan lembaga-lembaga pendidikan Islam yang muncul sejak kehadiran Islam itu sendiri yang dibawa oleh Nabi Muhammad serta peran yang dimainkannya dalam transmisi ilmu, seperti lembaga kuttab (lembaga pendidikan dasar yang mengajarkan baca tulis), masjid, madrasah, dan lembaga pendidikan lainnya seperti Bayt al-Hikmah, dan Halaqah. Armani Arief, Reformulasi Pendidikan Islam, (Jakarta: Ciputat Press, 2005), 110-112.
} 
cemerlang di masa silam dan tidak semata-mata menggantungkan pada penemuan orang Barat. Kita harusnya bisa menemukan sendiri teori-teori itu, dan semua ini menjadi tugas kita bersama.

Menurut Prof. Abdus Salam -satu-satunya ilmuwan Muslim yang hingga sekarang berhasil memperoleh Hadiah Nobel Fisika pada tahun 1979- terdapat tiga sebab mengapa selama 350 tahun abad keemasan umat Islam menuntut dan mengembangkan ilmu pengetahuan ke taraf yang amat tinggi:

a. Umat Islam benar-benar menghayati dan mengamalkan firman Allah swt, yang berulangkali diberikan di al-Quran dan Sunnah Nabi saw. Dalam banyak ayat, Allah swt selalu memerintahkan untuk mempelajari alam, berfikir, menalar, membuaat upayaupaya ilmiah dan menerapkannya dalam kehidupan bermasyarakat dan sebagainya.

b. Seorang 'Alim diberi status yang terhormat dalam Islam. Rasulullah saw memberi julukan "Pewaris Nabi" kepada cendekiawan Muslim, dalam banyak ayat, Allah swt juga banyak memuji keunggulan orang yang berilmu; seperti firman Allah swt: "Yang takut kepada Tuhan hanyalah orang-orang yang berilmu di antara hamba-hamba-Nya" (QS Fathir: 28) dan sabda Nabi: "Kelebihan orang yang berilmu daripada orang yang beribadat ialah laksana kelebihan bulan purnama daripada sekalian bintang-bintang". (HR Abu Dauwd, Tirmidzi dan Nasa'i).

c. Islam bersifat internasional, yakni bukan hanya bercorak antar bangsa dan lintas budaya, namun mereka juga sangat toleran terhadap mereka yang dari luar Islam beserta pemikiranpemikirannya.

Sebagaimana kondisi pendidikan di Indonesia, kondisi pendidikan Islam di Indonesia pun menghadapi berbagai persoalan dan kesenjangan dalam berbagai aspek yang lebih kompleks, yaitu: berupa persoalan dikotomi pendidikan, kurikulum, tujuan, sumber daya, serta manajemen pendidikan Islam. Upaya perbaikannya belum dilakukan secara mendasar, sehingga terkesan seadanya saja. Usaha pembaruan dan peningkatan pendidikan Islam sering bersifat sepotong-sepotong atau tidak komprehensif dan menyeluruh serta sebagian besar sistem dan lembaga pendidikan Islam belum dikelola secara profesional. Ukuran profesional guru saat ini sudah ada instrumen yang digunakan baik instrumen tes maupun pengamatan. Kaitannya dengan pendidikan Agama, kelihatannya ukuran profesional disini perlu lebih akurat lagi. Ini kaitannya dengan transfer materi PAI bukan hanya bersifat kognitif 
semata melainkan ada sikap dan afeksi yang dapat di tanamkan melalui pembiasaan dan keteladanan. ${ }^{7}$ Dalam hal media pembelajaran misalnya yang merupakan perantara untuk menyampaikan materi kepada peserta didik bisa dalam bentuk hardware ada pula dalam bentuk software. Seringkali ditemukan persoalan seperti; lemahnya kreasi dan inovasi pendidik dalam membuat media, distribusi media yang belum merata, keengganan dalam penggunaan media, kesulitan memperoleh media pembelajaran PAI. ${ }^{8}$

Masalah ini klasik namun tetap aktual sebab selama ini masih sering dipersoalkan, para pakar pendidikan (Islam), padahal dualisme dikotomik menjebak pada pemasungan diri atau pembelengguan diri menuju pada kejumudan dan kemunduran. Dualisme dikotomi ini, nampaknya sudah berkembang dan dianggap sebagai sistem pendidikan modern yang sesuai dengan zaman, sebenarnya hal ini tidak semestinya terjadi dalam pendidikan Islam, misal perbedaan dunia dan akhirat bukan berarti menafikan salah satu namun memperjelas satu sama lain agar manusia tidak terjebak dalam kebodohan dan kelalaian.

Memang ada sementara pihak yang mengklaim bahwa pada awalnya pihak Barat justru pernah belajar kepada Islam, tetapi sekarang sejarah sudah terbalik yaitu orang Islam yang belajar di Barat. Ini menunjukkan ilmuan Barat mampu mengolah epistimologi yang mereka pelajari dari Islam. Jadi sekarang cendekiawan muslim harus mampu pula mengolah kembali agar

\footnotetext{
7 Permasalahan yang muncul dalam pendidik adalah, sulitnya bagi peserta didik mencari teladanan dari guru. Misalnya keteladan dalam disiplin, peserta didik tidak jarang lebih dsiplin daripada gurunya ketika masuk ke kelas. Demikian juga dalam amaliyah sehari-hari, ketika tiba waktunya shalat lima waktu, tidak jarang peserta didik lebih dahulu melaksanakan shalat daripada guru sendiri. Solusinya adalah perlu adanya upaya pembinaan yang intens terhadap guru PAI untuk memberikan keteladan bagi peserta didik dalam bersikap dan melaksanakan amaliyah mahdhah dan ghairu mahdhah.

8 Indikator semua itu dapat dilihat dari seberapa banyak sekolah atau madrasah yang telah memiliki laboratorium PAI? Yang yang paling banyak adalah laboratorium IPA, Biologi, Bahasa dan komputer. Kalaupun pernah ada proyek semacam itu, diketahui publik hanya menjadi ladang korupsi bagi pejabat. Solusinya adalah, adanya upaya dari pihak penyelenggara pendidikan dalam mengupayakan labotorium PAI disetiap sekolah atau madrasah, agar peserta didik mudah belajar secara langsung materi-materi PAI yang memang dapat dipraktekkan. Misalnya mengurus jenazah, ibadah haji, zakat dsb. Selain itu dibutuhkan media-media gambar, video, buku-buku yang berkenaan dengan sejarah Islam dan tokoh-tokoh muslim. Media ini hendaknya di kelola secara serius, bisa saja dengan membuat video misalnya atau menggunakan youtube tetapi dengan sedikit kreasi mengeditnya agar sesuai dengan materi ajar PAI.
} 
epistimologi Barat dapat bersahabat dengan Islam. ${ }^{9}$ Seharusnya pendidikan Islam tidak menghendaki terjadinya dikotomi keilmuan, sebab dengan adanya sistem dikotomi menyebabkan sistem pendidikan Islam menjadi sekularistis, rasionalis-empiris, intuitif dan matrealistis. Keadaan tersebut tidak mendukung tata kehidupan umat yang mampu melahirkan peradaban Islam. Kita tahu Islam untuk semua, bukan milik pribadi, kelompok bahkan Nabi sekalipun. Dengan kata lain tidak ada yang "monopoli Islam". Penulis tegaskan Islam adalah Islam untuk semua makhluk. ${ }^{10}$

Usaha pembaruan pendidikan Islam secara mendasar selalu dihambat berbagai masalah, mulai dari persoalan dana sampai tenaga ahli, sehingga "Pendidikan Islam dewasa ini terlihat orientasinya yang semakin kurang jelas". Dengan kenyataan ini maka sebenarnya "sistem pendidikan Islam haruslah senantiasa mengorientasi diri untuk menjawab kebutuhan dan tantangan yang muncul dalam masyarakat sebagai konsekuensi logis dari perubahan. ${ }^{11}$

\section{Membentuk Pendidikan Madani}

Terkait dengan pemetaan pemikiran pendidikan Islam, dapat disimpulkan bahwa untuk menuju pembentukan masyarakat madani di Indonesia terdapat sejumlah corak pemikiran, yaitu tradisional-klasik, modern-sekuler, dan konvergensi. Sedangkan tipologi pemikiran Islam yang berkembang antara lain adalah klasik-konservatif dan modern-progresif. Dialektika pun kemudian terjadi dimulai dari konsensus para ahli bahwa al-Quran dan Hadis merupakan sumber utama dalam menggali masalah filosofis pendidikan Islam.

Dalam usaha pembaharuan pendidikan Islam perlu dirumuskan secara jelas implikasi ayat-ayat al-Qur'an dan hadits yang menyangkut dengan "fitrah" atau potensi bawaan, misi dan tujuan hidup manusia. Konsep dasar teoritis pendidikan Islam, harus ditempatkan dalam konteks supra sistem masyarakat madani di mana pendidikan itu akan diterapkan. Apabila terlepas dari konteks "masyarakat madani", maka pendidikan menjadi tidak relevan dengan kebutuhan umat Islam pada kondisi masyarakat

\footnotetext{
${ }^{9}$ Muslih Usa, Pendidikan Islam di Indonesia Antara Cita dan Fakta, (Yogyakarta: Tiara Wacana, 1991), 3-4.

10 Hasbullah, Kapita Selekta Pendidikan Islam di Indonesia, Jilit 2, (Jakarta Raja Grafindo Persada, 2002), 6-7.

11 Hujair AH. Sanaky, Paradigma Pendidikan Islam: Membangun Masyarakat Madani Indonesia, (Yogyakarta: Safiria Insania Press, 2003), 9.
} 
tersebut (masyarakat madani). Jadi, kebutuhan umat yang amat mendesak sekarang ini adalah mewujudkan dan meningkatan kualitas manusia Muslim menuju masyarakat madani. Untuk itu umat Islam di Indonesia dipersiapkan dan harus dibebaskan dari ketidaktahuannya (ignorance) akan kedudukan dan peranannya dalam kehidupan "masyarakat madani" dalam konteks kehidupan berbangsa dan bernegara. Pendidikan Islam haruslah dapat meningkatkan mutu umatnya dalam menuju "masyarakat madani". Kalau tidak umat Islam akan ketinggalan dalam kehidupan "masyarakat madani" yaitu masyarakat ideal yang dicita-citakan bangsa ini. Maka tantangan utama yang dihadapi umat Islam sekarang adalah peningkatan mutu sumber insaninya dalam menempatkan diri dan memainkan perannya dalam komunitas masyarakat madani dengan menguasai ilmu dan teknologi yang berkembang semakin pesat. Karena, hanya mereka yang menguasai ilmu dan teknologi modern dapat mengolah kekayaan alam yang telah diciptakan Allah untuk manusia dan diamanatkan-Nya kepada manusia sebagai khalifah dimuka bumi ini untuk diolah bagi kesejahteraan umat manusia.

Maka masyarakat madani yang diprediski memiliki ciri; Universalitas, Supermasi, Keabadian, Pemerataan kekuatan, Kebaikan dari dan untuk bersama, Meraih kebajikan umum, Perimbangan kebijakan umum, Piranti eksternal, Bukan berinteraksi pada keuntungan, dan Kesempatan yang sama dan merata kepada setiap warganya. Atas dasar konsep ini, maka konsep filsafat dan teoritis pendidikan Islam dikembangkan sebagai prinsip-prinsip yang mendasari keterlaksanaannya dalam kontek lingkungan masyarakat madani tersebut, sehingga pendidikan relevan dengan kondisi dan ciri sosial kultural masyarakat tersebut.

Selanjutnya menyatukan pendidikan yang teosentris dan antroposentris menjadi holistik secara integral. Pengembangan pola pemikiran pendidikan Islam kemudian dikembangkan ke arah rekonstruksi sosial dan paradigma pendidikan pembebasan. Terakhir dilakukan upaya membangun pendidikan berbasis nilai Islami, humanis, memberdayakan, dan membebaskan. ${ }^{12}$

\footnotetext{
12 Adapun terkait pembaruan pendidikan Islam di Indonesia, dapat disimpulkan bahwa basis yang digunakan adalah pendidikan madani yang memberdayakanmembebaskan. Basis pembaruan ini berupa pendidikan dengan fondasi religius, demokasi, membangun sikap toleransi, berbasis hukum, membangun sikap egalitarian, menjunjung tinggi martabat manusia, berbasis kemajemukan
} 
Untuk menghadapi dan membangun masyarakat madani di Indonesia diperlukan usaha pembaruan pendidikan Islam secara mendasar, yaitu 1) Perlu pemikiran kembali konsep pendidikan Islam yang betul-betul didasarkan pada asumsi dasar tentang manusia, terutama pada fitrah atau potensi, ${ }^{13}$ Belajar ialah suatu proses yang dilakukan individu untuk memperoleh suatu perubahan tingkah laku yang baru secara keseluruhan, sebagai hasil pengalaman individu itu sendiri dalam interaksi dengan lingkungannya. Kegagalan dunia pendidikan dalam menyiapkan masa depan umat manusia adalah merupakan kegagalan proses belajar mengajar oleh guru dan murid adalah kegagalan pendidikan itu sendiri. Dalam teori pendidikan hal semacam ini tidak menjadi masalah namun dalam realitas hal semacam ini menjadi problem pendidikan Islam.2) Pendidikan Islam harus menuju pada integritas antara ilmu ukhrowi dan ilmu duniawi untuk tidak melahirkan jurang pemisah antara ilmu agama dan ilmu bukan agama, karena dalam pandangan Islam bahwa Ilmu pengetahuan adalah satu yaitu berasal dari Allah SWT, ${ }^{14}$ Masalah ini klasik

budaya, berbasis wawasan global, berbasis anti kekerasan, dan berbasis anti korupsi.

13 Dalam proses belajar mengajar dibutuhkan hubungan yang harmonis antara guru dan murid. Tentunya tidak hanya memiliki ikatan secara lahiriah, struktural namun lebih dalam lagi harus memiliki ikatan batin untuk belajar dan mengajar bersama; bukan berarti meninggalkan kredibilatas atau eksistensi sebagai guru. Guru bukan segala-galanya, namun guru adalah pembimbing dengan kasih sayang bukan sebagai monster (killer). Sebaliknya murid jangan menjadikan guru sebagai orang yang ditakuti dan dijauhi sehingga belajar hanya berkutat pada ruangan keseharian yang menjenuhkan. Di mana saja dan kapan saja dapat belajar bersama tidak ada sekat yang membatasi bukan berarti bebas yang tak punya aturan. Proses belajar mengajar tidak hanya berkutat pada materi pelajaran. Persoalan hidup dan persoalan yang dihadapi harus menjadi persoalan yang harus dipecahkan serta direspon oleh guru. Mu'arif, Wacana Pendidikan Kritis, (Yogyakarta: IRCiSoD, 2005), 132.

14 Memang ada sementara pihak yang mengklaim bahwa pada awalnya pihak Barat justru pernah belajar kepada Islam, tetapi sekarang sejarah sudah terbalik yaitu orang Islam yang belajar di Barat. Ini menunjukkan ilmuan Barat mampu mengolah epistimologi yang mereka pelajari dari Islam. Jadi sekarang cendekiawan muslim harus mampu pula mengolah kembali agar epistimologi Barat dapat bersahabat dengan Islam. Seharusnya pendidikan Islam tidak menghendaki terjadinya dikotomi keilmuan, sebab dengan adanya sistem dikotomi menyebabkan sistem pendidikan Islam menjadi sekularistis, rasionalis-empiris, intuitif dan matrealistis. Keadaan tersebut tidak mendukung tata kehidupan umat yang mampu melahirkan peradaban Islam. Kita tahu Islam untuk semua, bukan milik pribadi, kelompok bahkan Nabi sekalipun. Dengan kata lain tidak ada yang "monopoli Islam". Penulis tegaskan Islam adalah Islam untuk semua makhluk. Muslih Usa, Pendidikan Islam di 
namun tetap aktual sebab selama ini masih sering dipersoalkan, para pakar pendidikan (Islam), padahal dualisme dikotomik menjebak pada pemasungan diri atau pembelengguan diri menuju pada kejumudan dan kemunduran. Dualisme dikotomi ini, nampaknya sudah berkembang dan dianggap sebagai sistem pendidikan modern yang sesuai dengan zaman, sebenarnya hal ini tidak semestinya terjadi dalam pendidikan Islam, misal perbedaan dunia dan akhirat bukan berarti menafikan salah satu namun memperjelas satu sama lain agar manusia tidak terjebak dalam kebodohan dan kelalaian. Ekses dari dipisahkannya duniawi dari ukhrowi antara lain:

a. Masing-masing pihak tegar dipihakmya sendiri, tanpa ada titik pertemuan, timbul faham dari agamawan bahwa ilmuwan telah keluar dari agama, sebaliknya para ilmuwan menganggap agamawan adalah orang yang kolot dan ketinggalan zaman.

b. Muncul dikotomi antara ilmuwan dan ulama atau "kesobongan ilmiah" antara keduanya.

c. Ekses terhadap al-Quran, akibat kurangnya ilmu pengetahuan Umum bagi penterjemah maka akan keringlah terjemahan alQuran yang mengandung makna yang sangat tinggi, Shanya karena tidak sampainya keilmuan penterjemah.

3) Pendidikan didesain menuju tercapainya sikap dan perilaku "toleransi", lapang dada dalam berbagai hal dan bidang, terutama toleran dalam perbedaan pendapat dan penafsiran ajaran Islam tanpa melepaskan pendapat atau prinsipnya yang diyakini, 4) Pendidikan yang mampu menumbuhkan kemampuan untuk berswadaya dan mandiri dalam kehidupan, 5) Pendidikan yang menumbuhkan etos kerja, mempunyai aspirasi pada kerja, disiplin dan jujur, 6) Pendidikan Islam perlu didesain untuk mampu menjawab tantangan masyarakat untuk menuju masyarakat madani serta lentur terhadap perubahan zaman dan masyarakat. ${ }^{15}$

Indonesia Antara Cita dan Fakta, (Yogyakarta: Tiara Wacana, 1991), 3-4. Lihat Juga: Hasbullah, Kapita Selekta Pendidikan Islam di Indonesia, Jilit 2, (Jakarta Raja Grafindo Persada, 2002), 6-7. Lihat juga: A. Qodri A. Azizy, Pendidikan (Agama) untuk Membanggun Etika Sosial, (Semarang: Aneka Ilmu, 2003), 2934.

15 Ketatnya kompetisi global, seseorang dituntut untuk semakin profesional, mempunyai skill yang berkualitas untuk mampu berkompetisi. Learning to be, pendidikan harus mampu membimbing peserta didik pada sikap tahu diri, sikap memahami diri sendiri, sadar kemampuan diri sendiri dan nantinya akan mampu menjadikan dirinya mandiri. Di samping itu, learning to be (belajar untuk hidup) juga memberi arti mengajarkan sadar lingkungan untuk menjaga bumi yang dihuni dari kerusakan. Learning to live together, pendidikan 
Pada prinsipnya peserta didik itu sudah mempunyai pengetahuan dasar. Tugas guru adalah merangsang peserta didik belajar menemukan pengetahuan melalui diskusi, discovery yang dirancang melalui diskusi kelompok atau tugas individu. ${ }^{16}$

Untuk dapat membuat kurikulum yang tepat dan serasi dengan tujuan pendidikan, maka harus dimulai dari menganalisa tujuan pendidikan itu. Tujuan pendidikan senantiasa berupa pengungkapan corak diri bernilai tinggi (intelektual, kritis atau peka terhadap realitas sosial dan bertaqwa) yang dimaksudkan sebagai pengabdian terhadap Allah SWT. ${ }^{17}$ Namun yang banyak kita lihat persoalan visi komitmen pemerintah dan kontruksi kesadaran masyarakat yang masih bernuansa fatalistik membuat keringnya kurikulum dari realitas sosial dengan segala perkembangan perubahan dan kemajuannya.

Pendidikan menganut asas subject matter oriented yang membebani peserta didik dengan informasi-informasi kognitif dan motorik yang kadang-kadang kurang relevan dengan kebutuhan dan tingkat perkembangan psikologis mereka. Pendidikan yang menyangkut ranah kognitif sudah dijalankan dengan perhatian yang besar. Pengelolaan pengajaran yang ada memberi kesan terlalu berorientasi pada ipteks termasuk juga keterampilan motorik terlalu berorientasi pada teknis. Dengan asas ini dapat

memiliki kemampuan untuk menyadarkan siswa akan "pluralisme". Hal ini dapat terwujud jika setiap orang bersedia menerima kenyataan akan adanya perbedaan. A. Qodri A. Azizy, Pendidikan (Agama) untuk Membanggun Etika Sosial, (Semarang: Aneka Ilmu, 2003), 3.

16 Secara umum perkembangan metodologi ini dalam mata pelajaran PAI tidak ada masalah. Yang sering terjadi permasalahan pada saat mengajarkan materi tertentu, sulit membiarkan peserta didik berdiskusi sendiri tanpa bimbingan yang baik. Misalnya dalam keterampilan membaca Al-Qur'an pada mata pelajaran al-Qur'an Hadits, tidak mungkin membiarkan siswa belajar sendiri atau diskusi membaca al-Qura'an tanpa bimbingan langsung oleh guru. Demikian halnya dalam mata pelajaran akidah akhlak aspek keimanan. Keimanan itu pada tahap usia dini harus lebih banyak penanaman melalui doktrinasi karena secara intelektual mereka belum dapat diajak berpikir halhal yang absrak. Misalnya dalam menanamkan keyakinan hal-hal yang gaib, sulit bagi guru untuk menjelaskan adanya malaikat, jin, hari akhir karena diperlukan tingkat intelektual yang memadai. Solusinya adalah dengan tidak menafikan metodologi konvensional yang digunakan oleh guru-guru dimasa lampau dalam menanamkan keyakinan melalui doktrinasi. Tentu dengan memadukan metodologi baru seperti model-model pembelajaran secara sinergi. Metodologi baru ini diperlukan untuk membuat suasana pembelajaran tetap menarik dan menyenangkan.

17 Burlian Somad, Beberapa Persoalan dalam Pendidikan Islam, ( Bandung: al Ma'arif, 1981), 103-104. 
dihasilkan lulusan yang pandai, cerdas, dan terampil; tetapi kepandaian dan kecerdasan intelektual tersebut kurang diimbangi dengan kecerdasan emosional. Keadaan demikian terjadi karena kurangnya perhatian terhadap ranah afektif. Padahal ranah afektif sama penting peranannya dalam membentuk perilaku peserta didik. Sekarang, dalam mendukung pelaksanaan demokratisasi pendidikan, tibalah saatnya mengubah asas subject matter oriented ke student oriented. Orientasi pendidikan yang bersifat student oriented lebih menekankan pada pertumbuhan, perkembangan, dan kebutuhan peserta didik secara utuh baik lahir maupun batin. Dalam hal ini kecerdasan otak memang penting, tetapi kecerdasan emosional juga tidak kalah pentingnya.

Dalam suasana PBM yang demokratis terjadi egalitarian (kesetaraan atau sederajat dalam kebersamaan) antara pendidik dengan peserta didik. Pengajaran tidak harus top down namun diimbangi dengan bottom up sehingga tidak ada lagi pemaksaan kehendak pendidik tetapi akan terjadi tawar-menawar kedua belah pihak dalam menentukan tujuan, materi, media, PBM, dan evaluasi hasil belajarnya.

Demikian juga perlunya pendidikan yang berakar dari budaya, Yaitu pendidikan yang tidak meninggalkan akar sejarah baik secara kemanusiaan umumnya maupun sejarah kebudayaan suatu bangsa. Pendidikan ini diharapkan dapat membentuk manusia yang mempunyai kepribadian, harga diri dan percaya pada diri sendiri untuk membangun peradaban berdasarkan budaya.

Dengan konsep pendidikan di atas akhirnya dapat dijadikan desain model pendidikan Islam untuk membangun masyarakat madani. Dalam bentuk operasionalnya sebagai berukut: 1. Mendesain model pendidikan umum Islami yang handal dan mampu bersaing dengan lembaga pendidikan yang lain. Dengan demikian visi misi dan tujuan pendidikan, kurikulum, materi pembelajaran, metode pembelajaran, manajemen pendidikan harus disesuaikan dengan tuntutan

zaman.

2. Model pendidikan Islam yang tetap mengkhususkan pada desain pendidikan keagamaan, yaitu benar-benar sesuai dengan konsepkonsep

Islam.

3. Model pendidikan agama Islam tidak hanya dilaksanakan di sekolah formal tetapi juga di luar sekolah seperti di lingkungan keluarga masyarakat sehingga pendidikan agama dapat ditanamkan dan disosialisasikan yang menjadi kebutuhan peserta didik, akhirnya pendidikan agama Islam bukan lagi berupa 
pengetahuan yang di hafal tetapi menjadi kebutuhan dan perilaku aktual.

Dalam konteks ini juga perlu pemikiran kembali tujuan dan fungsi lembaga- lembaga pendidikan Islam yang ada. Memang diakui bahwa penyesuaian lembaga-lembaga pendidikan akhir-akhir ini cukup menggembirakan, artinya lembaga-lembaga pendidikan memenuhi keinginan untuk menjadikan lembaga-lembaga tersebut sebagai tempat untuk mempelajari ilmu umum dan ilmu agama serta keterampilan. Tetapi pada kenyataannya penyesuaian tersebut lebih merupakan peniruan dengan tambal sulam atau dengan kata lain mengadopsi model yang telah dilakukan oleh lembaga-lembaga pendidikan umum, artinya ada perasaan harga diri bahwa apa yang dapat dilakukan oleh lembaga-lembaga pendidikan umum dapat juga dilakukan oleh lembaga-lembaga pendidikan agama, sehingga akibatnya beban kurikulum yang terlalu banyak dan cukup berat dan bahkan terjadi tumpang tindih.

Lembaga-lembaga pendidikan Islam mengambil secara utuh semua kurikulum (non-agama) dari kurikulum sekolah umum, kemudian tetap mempertahankan sejumlah program pendidikan agama, sehingga banyak bahan pelajaran yang tidak dapat dicerna oleh peserta didik secara baik, sehingga produknya (hasilnya) serba setengah-tengah atau tanggung baik pada ilmu-ilmu umum maupun pada ilmu-ilmu agama. Untuk itu, lembaga-lembaga pendidikan Islam sebenarnya mulai memikirkan kembali disain program pendidikan untuk menuju masyarakat madani, dengan memperhatikan relevansinya dengan bentuk atau kondisi serta ciri masyarakat madani.

Dari pembahasan di atas, ada beberapa indikator sebagai usaha pembaruan pendidikan Islam, yaitu: setting pendidikan, lingkungan pendidikan, karekteristik tujuan. Perlu diketahui bahwa suatu usaha pembaruan pendidikan terarah dengan baik apabila didasarkan pada kerangka dasar filsafat dan teori pendidikan yang mantap. Filsafat pendidikan hanya dapat dikembangkan berdasarkan asumsi-asumsi dasar yang kokoh dan jelas tentang manusia, baik sebagai individu maupun sebagai anggota masyarakat, hubungannya dengan lingkungan, alam semesta, akhiratnya, dan hubungannya dengan Maha Pencipta, sedangkan teori pendidikan dapat dikembangkan atas dasar pertemuan antara pendekatan filosofis dan pendekatan empiris.

Dengan demikian, kerangka dasar pertama pembaruan pendidikan Islam adalah "konsepsi filosofis" dan "teori pendidikan" yang didasarkan pada asumsi-asumsi dasar tentang manusia yang hubungannya dengan masyarakat lingkungan dan ajaran Islam. 


\section{Membangun Sistem Pendidikan Islam}

Langkah awal yang dilakukan dalam mengadakan perubahan pendidikan adalah merumuskan "kerangka dasar filosofis pendidikan" yang sesuai dengan ajaran Islam, kemudian mengembangkan secara "empiris prinsip-prinsip" yang mendasari keterlaksanaannya dalam konteks lingkungan (sosial dan kultural) tanpa kerangka dasar "filosofis" dan 'teoritis" yang kuat, maka pembaruan pendidikan Islam tidak punya pondasi yang kuat dan juga tidak mempunyai arah yang pasti. Kemudian langkah selanjutnya adalah mengembangkan kerangka dasar sistemik, yaitu kerangka dasar filosofis dan teoritis pendidikan Islam harus ditempatkan dalam konteks supra - sistem masyarakat, bangsa dan negara serta kepentingan umat dimana pendidikan itu diterapkan. Apabila terlepas dari konteks ini, pendidikan akan menjadi tidak relevan dengan kebutuhan masyarakat, bangsa dan negara Indonesia dalam menghadapi tuntutan perubahan menuju "masyarakat madani" Indonesia.

Dan inti dari masalah yang dihadapi Umat Islam hari ini adalah system pendidikan yang banyak berlaku. Di sekolah-sekolah hari ini, murid yang beragama Islam, dijauhkan dari warisan dan gaya Islam. Sistem pendidikan ini ibarat mesin pencuci otak yang mengubah paradigma mereka ke dalam sebuah karikatur Barat. Disinilah keinginannya untuk ruju' ila al-Islam (kembali kepada Islam) terhalang karena keragu-raguan yang ditanamkan oleh system tersebut dalam ranah pemikirannya.

Konsep ideal pendidikan untuk pembangunan masa depan Indonesia, yaitu dengan penyiapan sumber daya manusia (SDM) yang punya soft skill dan hard skill. Banyak pakar sepakat soft skill lebih penting daripada hard skill, seperti Daniel Goleman yang mengunggulkan kecerdasan emosi (EQ) daripada kecerdasan intelektual (IQ) dan Robert Strenberg yang memperkenalkan istilah successful intelegence (SI) yang dianggap lebih penting dari hard skill. Seorang dengan SI tinggi akan meraih sukses karena mampu memotivasi dirinya untuk terus maju, mengontrol emosi, berani mengambil resiko, fokus, mampu memecahkan masalah, menerjemahkan pikiran dalam aksi nyata serta mampu berfikir kreatif, analisis dan praktis yang seimbang.

Pertanyaannya, mengapa sistem pendidikan kita belum menghasilkan successful intelegence tinggi?? Banyak faktor yang melatar belakangi seperti kurikulum, kualitas guru, fasilitas sekolah dan sebagainya, namun yang cukup dominan adalah 
system pendidikan yang terlalu berorientasi akademik dan proses belajar yang tidak jauh dari hafalan, latihan berulang, instruksi terstruktur dan pengajaran satu arah. Ekses dari orientasi nilai adalah kemungkinan terbentuknya sifat "takut salah", takut mengambil inisiatif, menghindari resiko, takut berbeda, takut dikritik dan mencari zona aman yang menghasilkan siswa yang tidak siap menghadapi tantangan hidup modern.

Sistem seperti ini juga bisa membuat stress bisa memunculkan sifat reptile yang reaktif dan impulsive, maraknya tawuran dan sikap brutal siswa seperti yang banyak diberitakan, mungkin disebabkan peran otak reptil ini. Diperlukan perubahan besar pada pendidikan kita dan dunia akan terus berubah dengan kecepatan eksponensial. SI makin urgen untuk kehidupan anak kita yang keadaannya lebih kompleks.

Setidak-tidaknya problematika pendidikan Islam meliputi: Problem kerangka sistem dan metode pendidikan Islam, problem komersialisasi pada lembaga pendidikan Islam, problem dikotomi dalam sistem pendidikan Islam, problem lemahnya semangat iqra' dalam pendidikan Islam, problem metodologis dalam pendidikan Islam, Problem epistimologis pendidikan Islam, Problem nilai (dekadensi moral) pendidikan Islam, Problem ketidakserasian kurikulum dalam pendidikan Islam.

Sistem pendidikan Islam di masa kini dan masa yang akan datang perlu dipikirkan dan dibicarakan sebab-sebab permasalahannya, antara lain: Pertama, bahwa penyelenggaraan pendidikan Islam secara formal/ informal belum sesuai dengan pengertian pendidikan Islam itu sendiri; Kedua, bahwa sistem dan metode itu masih dalam lingkaran pendakalan (proses de islamisasi).

Untuk mengakhiri pembahasan ini, mengutip Johar dalam bukunya Pengembangan Pendidikan Nasional Menyongsong Masa Depan" menyatakan bahwa pendidikan harus berdasarkan paradigma kebangsaan yang religius. Artinya kepemilahaan kita dalam melaksanakan pendidikan adalah mencerdaskan kehidupan bangsa yang religius. Konsekuensi dari itu maka pendidikan kita harus harus dilaksanakan dengan cara: (1) Pendidikan untuk membangun integritas ilmu dan agama; (2) Pendidikan kita dilaksanakan dengan Iqra', mengkaji ciptaan Tuhan utuk memperoleh ilmu Tuhan (3) Pendidikan kita dilaksanakan untuk mengamalkan ajaran Tuhan; (4) Pendidikan kita dilaksanakan dengan misi tugas hidup di bumi sebagai wakil Tuhan; (5) 
Pendidikan kita seharusnya mengkaji realita; (6) Pendidikan harus mampu membangun tauhid vertikal dan tauhid social. ${ }^{18}$

\section{Kesimpulan}

Berdasarkan uraian singkat di atas, maka dapat diambil kesimpulan antara lain: pertama, pemikiran pembaruan pendidikan Islam di Indonesia adalah harus sesuai dengan kebutuhan masyarakat melalui pembaruan pada sistem dan penyelenggaraan pendidikan Islam itu sendiri. Konsep dasar pembaharuan pendidikan harus didasarkan pada asumsi- asumsi dasar tentang manusia menurut aajaran Islam, filsafat dan teori pendidikan Islam yang dijabarkan dan dikembangkan berdasarkan asumsi-asumsi tentang manusia dan lingkungannya. Atau dengan kata lain pembaharuan pendidikan Islam adalah filsafat dan teori pendidikan Islam yang sesuai dengan ajaran Islam, dan untuk lingkungan (sosial-kultural) yang dalam hal ini adalah masyarakat madani.

Menyarakat madani merupakan suatu ujud masyarakat yang memiliki kemandirian aktivitas dengan ciri: universalitas, supermasi, keabadian, pemerataan kekuatan, kebaikan dari dan untuk bersama, meraih kebajikan umum, piranti eksternal, bukan berinteraksi pada keuntungan, dan kesempatan yang sama dan merata kepada setiap warganya. ciri masyarakat ini merupakan masyarakat yang ideal dalam kehidupan. Untuk Pemerintah pada era reformasi ini, akan mengarakan semua potensi bangsa berupa pendidikan, ekonomi, politik, hukum, sosial budaya, militer, kerah masyarakat madani yang dicita- citakan.

Konsep dasar pendidikan Islam supaya relevan dengan kepentingan umat Islam dan relevan dengan disain masyarakat madani. Maka penerapan konsep dasar filsafat dan teori pendidikan harus memperhatikan konteks supra sistem bagi kepentingan komunitas "masyarakat madani" yang dicita-citakan bangsa ini.

\section{Daftar Pustaka}

Ahmadi, Abu Noor Salimi. Dasar- dasar Pendidikan Agama Islam, (Jakarta: PT Bumi Aksara, 2004)

18 Djohar, Pengembangangan Pendidikan Nasional Menyongsong Masa Depan, (Yogyakarta: Grafika Indah, 2006), 57-63. 
Aly, Hery noer. H. Munzier. Watak Pendidikan Islam, (Jakarta: Friska Agung Insani, 2003)

Amir, Syarifuddin. Garis- Garis Besar Fiqih, (Bogor: Kencana, 2003)

Anshari, Hafi. Pengantar Ilmu Pendidikan, (Surabaya: Usaha Nasional, 1982)

Anwar, Qamari. Pendidikan Sebagai Karakter Budaya Bangsa, (Jakarta: UHAMKA Press, 2003)

Arifi, Ahmad, Politik Pendidikan Islam; Menelusuri Ideologi dan Aktualisasi Pendidikan Islam Di Tengah Arus Globalisasi, (Yogyakarta: Teras. 2009).

Arief, Armani, Reformulasi Pendidikan Islam, (Jakarta: Ciputat Press. 2005).

Azizy, A. Qodri, Pendidikan (Agama) untuk Membanggun Etika Sosial, (Semarang: Aneka Ilmu. 2003).

Azra, Azyumardi, Esei- esei Intelektual Muslim \& Pendidikan Islam, (Jakarta: Logos.1999).

Djohar. Pengembangangan Pendidikan Nasional Menyongsong Masa Depan, (Yogyakarta: Grafika Indah. 2006)

Faisal, Jusuf Amir. Reorientasi Pendidikan Islam, (Jakarta: Gema Insani, 1995).

Freire, Paulo. Politik Pendidikan: Kebudayaan, Kekuasaan dan Pembebasan, terj. Agung Prihantoro dan Fuad Arif Fudiyartanto. Cet. II; (Yogyakarta: Pustaka Pelajar. 2000).

Hanif Dhakiri, Muh. Paulo Freire Islam Pembebasan, (Jakarta: Penerbit Pena. 2000)

Hasbullah, Kapita Selekta Pendidikan Islam di Indonesia, Jilit 2, (Jakarta Raja Grafindo Persada, 2002).

Hitti, Philips K., History of the Arabs, first edition, and six edition, (USA.TT, 1968).

Hujair, AH. Sanaky. Paradigma Pendidikan Islam: Membangun Masyarakat Madani Indonesia, (Yogyakarta: Safiria Insania Press, 2003).

Kartono, Kartini. Tinjauan Politik Mengenai Sistem Pendidikan Nasional: Beberapa Kritik dan Sugesti. Cet.I, (Jakarta: Pradnya Paramita, 1997).

Khaldun, Ibn. Al-Muqaddimah, Terjm. Ahmadie Thoha, Cet. 1 (Jakarta: Pustaka Firdaus, 1986).

Knight, George R. Filsafat Pendidikan, (Yogyakarta: Gama Media.2007).

Ma'arif, Ahmad Syafi'i. Posisi sentral Al-Qur'an dalam studi Islam, (Yogyakarta: Tiara Wacana Yogya, 1989)

Mu'arif, Wacana Pendidikan Kritis, (Yogyakarta: IRCiSoD. 2005). 
Mulkhan, Abdul Munir. Paradigma Intelektual Muslim, (Yokyakarta:

Sipress, 1993)

Natsir, M. Kapita Selekta, (Jakarta: Bulan Bintang, 1973).

Qomar, Mujamil. Epistemologi Pendidikan Islam, (Jakarta: Penerbit Erlangga. 2005).

Sanaky, Hujair AH. Paradigma Pendidikan Islam: Membangun Masyarakat Madani Indonesia, (Yogyakarta: Safiria Insania Press, 2003)

Sardar, Ziaudin, Rekayasa Masa Depan Peradaban Muslim, terj, Rahmani Astuti, (Bandung: Mizan, 1992).

Somad, Burlian, Beberapa Persoalan dalam Pendidikan Islam, (Bandung: al Ma'arif. 1981).

Suharto, Toto, Pendidikan Berbasis Masyarakat Organik, (Bandung: Rineka Cipta, 2003)

Sihombing, Umberto. "Konsep dan Pengembangan Pendidikan Berbasis Masyarakat" dalam Fasli Jalal dan Dedi Supriadi (Eds.), Reformasi Pendidikan dalam Konteks Otonomi Daerah. Cet.I; (Yogyakarta: Adicita Karya Nusa. 2001).

Usa, Muslih, Pendidikan Islam di Indonesia Antara Cita dan Fakta, (Yogyakarta: Tiara Wacana.1991).

Wardi, Moh. "Problematika Pendidikan Islam Dan Solusi Alternatifnya (Perspektif Ontologis, Epistemologis dan Aksiologis)" Tadris Jurnal Pendidikan Islam STAIN Pamekasan, Volume 8 Nomor 1 Juni 2013. 